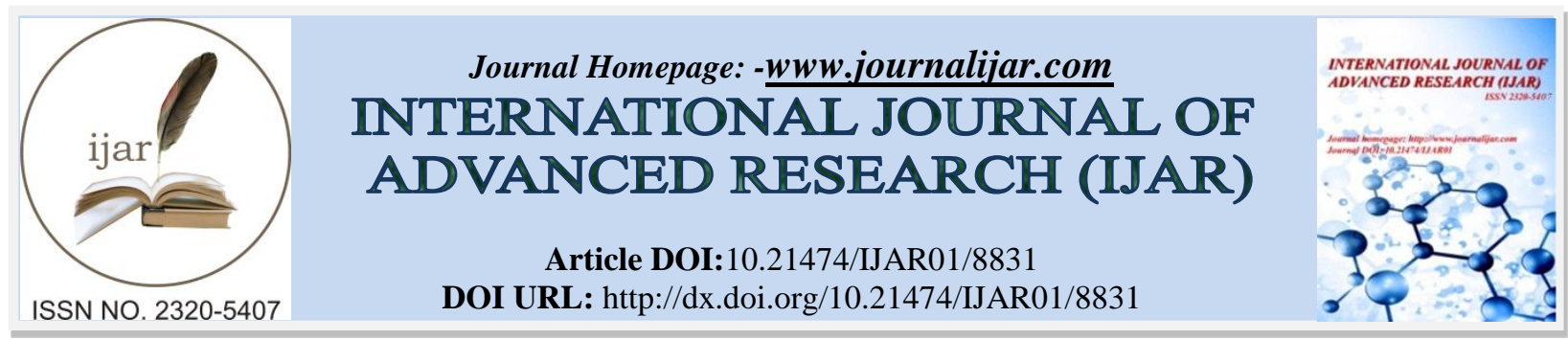

RESEARCH ARTICLE

\title{
YIELD OF SEVERAL PAPER CHILI (CAPSICUM ANNUM L.) VARIETIES AS THE EFFECT BY APPLICATION OF MYCORRHIZA IN SALINE SOIL.
}

Mizan Maulana ${ }^{1}$, Rita Hayati ${ }^{2}$ and Bakhtiar Basyah ${ }^{2}$.

1. Master student of Magister Agroecotechnology, Faculty of Agriculture, Universitas Syiah Kuala, Darussalam, Banda Aceh, Indonesia 23111.

2. Department of Agroecotechnology, Universitas Syiah Kuala, Darussalam, Banda Aceh, Indonesia 23111.

\section{Manuscript Info}

\section{Manuscript History}

Received: 06 February 2019

Final Accepted: 08 March 2019

Published: April 2019

Key words:-

Mycorrhiza, Varieties of chilli, Saline,

land, Capsicum annuum.

\begin{abstract}
Saline land is widely found in tidal areas or around the coast, saline soils are a limiting factor for people to manage economical valuable hoticultural crops such as paper chili, paper chili contains nutrients needed for health. Paper chili contains protein, fat, carbohydrates, calcium, phosphorus, iron, vitamins, and alkaloid compounds, such as capsaicin, flavenoid, and essential oils. The purpose of this study was to determine the effect of paper chili varieties and mycorrhiza types and the interactions between these two factors on the growth and yield of paper chilli plants on saline soil. The type Arbuscularmycorrhiza (AMF) used were; Glomus sp., Acaulospora and mixture, mean while several types of chili varieties namely Perintis, PM 999 and Lado on saline soil. The research was conducted at the Experimental Farm, Plant Disease Laboratory and Soil Biology Laboratory, Faculty of Agriculture, Syiah Kuala University, Darussalam, Banda Aceh. It was held from August to November 2018. The design used in this experiment was a $4 \times 3$ Factorial Randomized Block Design with 3 replications, as the result there were 12 treatment combinations. The results of this study indicate that, varieties have a very significant effect on the number of fruit crops significantly affect the weight of fruit crops. The type of mycorrhiza had a very significant effect on the number of fruit crops, and had no significant effect on the weight of the fruit of the crop, the weight of the wet crop, the dry weight of the crop, the wet weight of the root crop, the dry weight of the root crop, the root length of the crop. The use of mycorrhizae and varieties in saline soils can increase plant growth and yield and increase the weight of chili fruit supported by the input of the soil.
\end{abstract}

Copy Right, IJAR, 2019,. All rights reserved.

\section{Introduction:-}

Paper chili is a necessary vegetable commodity in daily life because it is useful as a food flavoring and paper chili contains necessary nutrients for health. Chili contains protein, fat, carbohydrates, calcium (Ca), phosphorus (P), iron (Fe), vitamins, and alkaloid compounds, such as capsaicin, flavenoid, and essential oils (Prajnanta, 2001). Saline soil is a soil with high salt mineral concentration. According to Sipayung (2003), plants can be disrupted by the value of 
electrical conductivity of more than $2 \mathrm{mmhos} / \mathrm{cm}$. The higher the value of EC, the more inhibited the growth and development of the plants. There are several issues in saline soil it is are to be used for cultivation crop, including low osmotic pressure, low nitrogen served concentratium, high natrium content and high soil $\mathrm{pH}$.

Arbuscular mycorrhiza fungi (AMF) is able to colonize plant roots in each type of ecosystem even in saline soils. Depending on the host plant, some AMF species are spread mainly in deep soil horizons. The AMF number is adjusted for extreme environmental conditions of saline land in central Argentina (Bacerra, 2014).

The superior variety is the technology component that is quickly adopted by farmers, because it is easy, inexpensive, and compatible with other technologies. By using superior varieties of nutrient imbalances, pest attacks and acidity problems are easily overcome. In addition to producing varieties and high productivity, plant breeding also gives attention to plant specific characteristics, such as tolerance to soil and climate that is not optimal, and tolerance to pests and diseases (Suhartina, 2005).

The purpose of this study was to determine the effect of chili varieties and the application of mycorrhiza types and interactions between these two factors on the growth and yield of chilli plants on saline soil.

\section{Materials and method:-}

The research was conducted at the Experimental Garden, Plant Disease Laboratory and Soil Biology Laboratory, Faculty of Agriculture, Syiah Kuala University, Darussalam Banda Aceh. This research was conducted in August to November 2017. The seeds used in this study were varieties of Perintis varieties, PM 999 and Lado. Mycorrhiza used in this study were mycorrhiza of Glomus sp, Acauluspora sp and mixtures obtained from the Bogor Agricultural Institute (IPB), Bogor. Saline soil used in this study was made with a concentration of $5 \mathrm{~kg}$ salt solution per 15 liters of water which given to soil as much as $200 \mathrm{ml}$. The soil has been analyzed with the value of EC (Electrical Conductivity) of $5.5 \mathrm{mS} / \mathrm{cm}$ and is included in the very high category according to the soil and plant research laboratory of the Faculty of Agriculture, Syiah Kuala University. The tools used in this research are $15 \mathrm{~kg}$ polybag, seed trey, meter bard, caliper, analytical scales, soil sieves, hoes, microscope Nikon SE 102 type Binocular brands, petri dishes, filters paper, tweezers, glass preparations, glass cover, oven, camera and plastic housing as a place to put trial polybags.

The design used in this experiment was a $4 \times 3$ Factorial Randomized Block Design with 3 replications, it had 12 treatment combinations consisting of two treatment factors, namely the first factor type of mycorrhiza and the second factor chili varieties. Data was analited using Microsoft Office Excel 2007 applications.

The green house used is located in the experimental garden at the Faculty of Agriculture, Syiah Kuala University. The soil was taken from Alue Naga Village, Syiah Kuala Banda Aceh. The soil is taken from the top soil layer with a depth of $0-25 \mathrm{~cm}$. Then the soil is sifted using a $2 \mathrm{~mm}$ sieve. The media stirred until it homogen. The soil was put in a $15 \mathrm{~kg}$ polybag and arranged according to the treatment plan. Artificial saline preparation, was done by preparing $5 \mathrm{~kg}$ of salt mixed with 15 liters of mineral water stirred until homogenly mixed, the dose of salt solution given is $200 \mathrm{ml}$ per polybag.

Each polybag was given mycorrhiza according to their respective types and controls (without of mycorrhiza addition). Mycorrhiza were placed in planting holes around the root area at a depth of $2-3 \mathrm{~cm}$ according to the treatment per plant before the seeds were planted in polybags. Then the planting holes that have been given mycorrhiza were covered again with soil. The application of mycorrhiza was done once during seed planting.

In the experimental polybag prepared and given the treatment of mycorrhiza a planting hole of 2-3 cm deep was made. Each planting hole was planted with 2 seed of chili. Then the planting hole was covered with soil and watered until the field capacity. One plant was selected and then transferred to a $15 \mathrm{~kg}$ polybag and maintained until harvesting time. Each unit of experimental unit consists of 3 experimental unit polybags

Maintenance activities carried out include watering, replanting, pest and disease control.Watering was done every day in the morning and evening. Watering was carried out by using spout until the field capacity. Pest and disease control is carried out by spraying active compound and deltamethrin fungicides when plants were attacked by pests and fungi with a concentration of $2 \mathrm{ml} / 1$ water. Harvesting was done after the plants are 90 days old with flushing fruit visilal characteristics 80 percent, Harvesting was done by picking fruit and stalks. 


\section{Observation of Chili Yield}

\section{Number of fruits per plant}

Observations were made at harvest at the ages of $90,95,100,105,110,115,120,125,130$, and 135 Day the day after planting by calculating the total number of red chili peppers.

\section{Fruit weight per plant (g)}

Measuring fruit weight was carried out at harvesting time, at the ages of 90, 95, 100, 105,110, 115, 120,125, 130, and 135 day by measuring the weight of chilli plants using analytical scales.

\section{Wet biomass weight (g)}

Observation of the plant's wet weight at the time after the age of 135 days it was done by removing the whole part of plant is dismantled and then cleaned the root using water, briefly aerated dried for a while and then the weight was using measure analytical scales.

\section{Dry biomass weight (g)}

After the age of 135 day the plants were dried after cutting their roots using an oven for $2 \times 24$ hours at $60 \mathrm{oC}$ to remove the water content and then it measured using analytical scale.

\section{Root wet weight (g)}

After the age of 135 day the root is cut at the base of the stem and then cleaned using water until the sticky soil on the root is lost, then weigh was measure using analytical scale.

\section{Root dry weight per plant (g)}

After the age of 135 day the cut roots were dried using an oven for 24 hours and then measured using analytical scale.

\section{Root length per plant $(\mathrm{g})$}

Measuring the root length was done twice, at the age of 45 day the root is cut at the base of the stem then cleaned using water until the sticky soil on the root was lost, then measured by the meter land.

\section{Result and Discussion:-}

\section{Result}

\section{Effect of varieties on the yield of chili plants on saline land}

The $F$ test results showed that chili varieties had a very significant effect on wet weight, number of fruit crops, dry weight plant fruit, significantly affected plant weight, but it had no significant effect on dry weight, root wet weight, root dry weight, length root. The number of planted fruit in several chili varieties experimented has a significant difference, the PM 999 variety was able to produce more chili fruit at the age of 110 days. The average number of fruit aged 110 HST on various varieties of treatment can be seen in Table 2. Table 2 shows that the average number of fruit crops found in the PM 999 variety is significantly different from the other two varieties. In these data the PM 999 variety is the best although when it compared to other varieties it is not too significant for other parameters of plants in saline soil.

Table 2:-Average number of fruits in various chili varieties

\begin{tabular}{|l|c|}
\hline \multicolumn{1}{|c|}{ Chili variety } & Number of fruits \\
\cline { 2 - 2 } & Total \\
\hline Perintis & $15,00 \mathrm{~b}$ \\
\hline PM 999 & $17,41 \mathrm{c}$ \\
\hline Lado & $12,75 \mathrm{a}$ \\
\hline HSD .05 & 0,79 \\
\hline
\end{tabular}

Table 3:-Average fruit weight of plants in various treatments of chili varieties

\begin{tabular}{|l|c|}
\hline \multicolumn{1}{|c|}{ Chili variety } & Fruit weight per plant (g) \\
\cline { 2 - 2 } & $\mathbf{1 1 0}$ day \\
\hline Perintis & $39,69 \mathrm{~b}$ \\
\hline PM 999 & $55,52 \mathrm{c}$ \\
\hline
\end{tabular}




\begin{tabular}{|l|c|}
\hline Lado & $32,87 \mathrm{a}$ \\
\hline HSD $.05^{.05}$ & 4,05 \\
\hline
\end{tabular}

The fruit weight was also greatly affected by the number of fruits, so when viewed from the parameters of the number of fruits, the PM 999 variety clearly has more weight than the Perintis or Lado varieties. that the heaviest weight of the chili fruit plantations was found in the PM 999 varieties which were significantly different from the other two varieties. The average fruit weight of the age of 110 day on various varieties of treatment can be seen in

Table 3.

Table 4:-Average wet biomasa weight at 110 day at various treatments of varieties

\begin{tabular}{|l|c|}
\hline \multicolumn{1}{|c|}{ Chili variety } & Stover wet weight of planting $(\mathbf{g})$ \\
\cline { 2 - 2 } & $\mathbf{1 1 0}$ day \\
\hline Perintis & $16,85 \mathrm{a}$ \\
\hline PM 999 & $25,89 \mathrm{~b}$ \\
\hline Lado & $25,69 \mathrm{~b}$ \\
\hline HSD .05 & 2,14 \\
\hline
\end{tabular}

Wet biomass plants with haight and a large number of branches will increase the amount of weight of the chili plants, in this case the PM 999 varieties compete with the Lado variety. The average wet weight of the age of 110 day on various varieties of treatment can be seen in Table 4 . Table 4 shows that the average wet weight of chili peppers at 110 day tends to be more expressed in the PM 999 variety, even though it is not significantly different from the variety Lado it is significantly different from Perintis varieties.

Table 5:-Average dry stover weight at 110 DAP at various treatments of varieties

\begin{tabular}{|l|c|}
\hline \multicolumn{1}{|c|}{ Chili variety } & Stover wet weight of planting (g) \\
\cline { 2 - 2 } & $\mathbf{1 1 0}$ day \\
\hline Perintis & 4,48 \\
\hline PM 999 & 6,06 \\
\hline Lado & 6,28 \\
\hline
\end{tabular}

Dried dry weight is dominated by lado varieties because the chili varieties of lado variety contain more water than the PM 999 variety. The average dry weight of the age of 110 day in various varieties can be seen in Table 5. Table 5 shows that the average dry weight chili at the age of 110 day tended to be more severe in Lado varieties, although statistically different but it was not significant with other varieties.

Table 6:-Average wet root weight at 110 day in various treatments of varieties

\begin{tabular}{|l|c|}
\hline \multirow{2}{*}{ Chili variety } & Wet root weight of roots per plant (g) \\
\cline { 2 - 2 } & $\mathbf{1 1 0}$ day \\
\hline Perintis & 2,05 \\
\hline PM 999 & 2,53 \\
\hline Lado & 2,51 \\
\hline
\end{tabular}

Root wet weight is influenced by the number of primary and secondary roots of each variety. The average root wet weight at 110 day at various varieties of treatment can be seen in Table 6 . Table 6 shows that the average chili root weight at $110 \mathrm{HST}$ which tends to be heavier was found in the PM 999 treatment although different but is not significant with other varieties.

Table 7:-Average dry root weight at 110 DAP in various treatments of varieties

\begin{tabular}{|l|c|}
\hline \multicolumn{1}{|c|}{ Chili variety } & Root dry weight per plant (g) \\
\cline { 2 - 2 } & $\mathbf{1 1 0}$ day \\
\hline Perintis & 0,56 \\
\hline PM 999 & 0,70 \\
\hline Lado & 0,72 \\
\hline
\end{tabular}


The dry weight of the roots of the Lado variety has a very high moisture content, after drying for 48 hours using an oven with a temperature of $600 \mathrm{C}$. The average root dry weight of 110 day at various varieties of treatment can be seen in Table 7. Table 7 shows that the average dry weight of chili root at the age of 110 HST which tends to be heavier was found in the Lado variety although it is statistically not significantly different from the varieties other.

Table 8:-Average root length of 110 day in various treatments of varieties

\begin{tabular}{|l|c|}
\hline \multicolumn{1}{|c|}{ Chili variety } & Root length per plant (g) \\
\cline { 2 - 2 } & $\mathbf{1 1 0 ~ H S T}$ \\
\hline Perintis & 16,80 \\
\hline PM 999 & 21,40 \\
\hline Lado & 17,45 \\
\hline
\end{tabular}

Root length was measured using a ruler, where the root roots of most root hairs were vertically vertical in the PM 999 varieties. The average root length of 110 day at various varieties of treatment can be seen in Table 8 . Table 8 shows that the average root length chili at the age of 110 day which tends to be longer found in the variety PM 999 , although statistically it is not real different to other varieties.

\section{The effect of the type of mycorrhiza on yields on chili plants on saline land}

The F test results showed that the type of mycorrhiza had no significant effect on fruit, wet biomass, dry weight, root weight, plant dry weight, root length of planting. Application of Acauluspora mycorrhiza was able to support chili plants to producing more fruit on of 110 DAP under various species of mycorrhiza (Table 9). Table 9 show that the large average number of chili fruit tunel on Acauluspora mycorrhiza which not significantly different with the mixture types but significantly different to the others treatments

Table 9:-Average number of fruits in various treatments of mycorrhiza types

\begin{tabular}{|l|c|}
\hline \multicolumn{1}{|c|}{ Types of mycorrhiza (10 g / plant) } & Number of fruits per plant \\
\hline Control & $12,00 \mathrm{a}$ \\
\hline Glomus & $14,88 \mathrm{~b}$ \\
\hline Acauluspora & $16,77 \mathrm{c}$ \\
\hline Mixture & $16,55 \mathrm{c}$ \\
\hline HSD $_{05}$ & 0,92 \\
\hline
\end{tabular}

Mixed mycorrhiza have a higher average on plant fruit weight followed by other types of mycorrhiza. The average fruit weight in various types of mycorrhiza treatments can be seen in Table 10. Table 10 shows that the average weight of fruit crops that tended to be heavier was found in mixed mycorrhiza, although not statistically different from other treatments.

Table 10:-Average fruit weight per plants it 110 DAP in treatments of mycorrhiza types

\begin{tabular}{|c|c|}
\hline \multirow[t]{2}{*}{ Type of mycorrhiza ( $10 \mathrm{~g} /$ plant) } & Fruit weight per plant (g) \\
\hline & total \\
\hline Control & 30,92 \\
\hline Glomus & 36,44 \\
\hline Acauluspora & 50,06 \\
\hline Mixture & 53,35 \\
\hline
\end{tabular}

Although the type of mycorrhiza had no significant effect on the wet crop weight, the type of glomus mycorrhiza was able to provide additional hyphae in several plant samples which were able to maximize the development of chili plant stems and branches. The average weighted weight of various types of mycorrhiza treatments can be seen in Table 11. Table 11 shows that the average wet crop weight of chili plants which tends to be heavier is found in the type of glomus mycorrhiza, although it is not statistically significant with other types of mycorrhiza.

Table 11:-Average wet crop weight at 110 DAP in treatments of mycorrhiza types

\begin{tabular}{|l|c|}
\hline \multicolumn{1}{|c|}{ Type of mycorrhiza (10g / plant) } & Wet stover weight per plant (g) \\
\hline Control & 21,90 \\
\hline Glomus & 28,27 \\
\hline
\end{tabular}




\begin{tabular}{|l|c|}
\hline Acauluspora & 20,15 \\
\hline Mixture & 20,91 \\
\hline
\end{tabular}

Glomus type mycorrhiza have a high value on dry biomass weight the average dry weight at age 110 day on various types of mycorrhiza can be seen in Table 12. Table 12 shows that the average dry weight of chili plants at the age of 110 day tends to be more weight was found in the type of glomus mycorrhiza, although statistically different was not significant with other treatments.

Table 12:-Average dry cropweight at 110 day in treatments of mycorrhiza types

\begin{tabular}{|l|c|}
\hline \multicolumn{1}{|c|}{ Type of mycorrhiza (10g/ plant) } & Dry stover plant weight (g) \\
\hline Control & 4,96 \\
\hline Glomus & 7,18 \\
\hline Acauluspora & 5,24 \\
\hline Mixture & 5,04 \\
\hline
\end{tabular}

The type of mycorrhiza had no significant effect on root wet weight at 110 DAP which was dominated by glomus mycorrhiza. The average wet stover weight at the age of 110 DAP in various types of mycorrhiza can be seen in Table 13. Table 13 shows that the average wet root weight of chili plants at the age of 110 day which tends to be heavier is found in glomus mycorrhiza species, although statistically different not real with other treatments.

Table 13:-Average wet root weight at 110 DAP in treatments of mycorrhiza types

\begin{tabular}{|l|c|}
\hline \multicolumn{1}{|c|}{ Type of mycorrhiza (10g/ plant) } & Wet weight of roots per plant (g) \\
\hline Control & 2,25 \\
\hline Glomus & 3,00 \\
\hline Acauluspora & 2,12 \\
\hline Mixture & 2,09 \\
\hline
\end{tabular}

Colonization of glomus mycorrhiza is able to maintain water content in dried roots compared to other types of mycorrhiza. Average dry root weight of 110 DAP in various types of mycorrhiza shown in Table 14 . Table 14 shows that the average dry root weight the age of 110 day which tends to be heavier is found in the type of glomus mycorrhiza, although statistically different to another

Table 14:-Average dry root weight at 110 DAP in treatments of mycorrhiza types

\begin{tabular}{|l|c|}
\hline \multicolumn{1}{|c|}{ Type of mycorrhiza (10g / plant) } & Root dry weight (g) \\
\hline Control & 0,64 \\
\hline Glomus & 0,85 \\
\hline Acauluspora & 0,61 \\
\hline Mixture & 0,54 \\
\hline
\end{tabular}

Glomus type mycorrhiza is able to increase the range of roots to capture water and nutrients by extending the roots of the chili plant. The average root length of 110 DAP in various types of mycorrhiza shown in Table 15 . Table 15 shows that the average dry root weight at the age of 110 day which tends to be heavier is found in the types of glomus mycorrhiza, although statistically different to another treatment.

Table 15:-Average root length ot 110 DAP in treatments of mycorrhiza types

\begin{tabular}{|l|c|}
\hline \multicolumn{1}{|c|}{ Type of mycorrhiza (10g/ plant) } & Root length (cm) \\
\hline Control & 17,22 \\
\hline Glomus & 22,38 \\
\hline Acauluspora & 17,54 \\
\hline Mixture & 17,04 \\
\hline
\end{tabular}

\section{Discussion:-}

The results of the soil support analysis in table 1 show that the nutrient content in the soil almost has a low nutrient level. $\mathrm{N}$ content of $0.06 \%$ (very low), P-available $9.15 \mathrm{mg} \mathrm{kg-1}$ (medium), organic C-0.55\% (very low), CEC 17.60 
cmol kg-1 (moderate), pH soil 6.08 (slightly acidic), electrical conductivity of 5.50 (very high) is until the soil grade texture F (sandy clay). In this case the soil contains high levels of saline that can be used in this study, there are some risks that occur in the field where the seed that has been sown does not grow or the simultaneous growth is small. With these soil conditions the application of mycorrhizae is able to help the seeds to grow and germinate in saline land conditions. Availability of $\mathrm{P}$ is also in the medium category excluding critical land $\mathrm{P}$. in this case $\mathrm{P}$ is sufficiently available to plants in saline soil conditions.

Table 1:-Results of soil analysis

\begin{tabular}{|l|c|c|}
\hline \multicolumn{1}{|c|}{ Types of Analysis } & Analysis Results & Category \\
\hline Soil Texture & & Sandy Clay Clay \\
Sand & $58 \%$ & \\
Dust & $21 \%$ & \\
Clay & $21 \%$ & Little sour \\
\hline $\mathrm{pH}\left(\mathrm{H}_{2} \mathrm{O}\right)$ & 6,06 & Low \\
$\mathrm{pH}(\mathrm{KCl})$ & 5,38 & Medium \\
\hline C-Organic & $0,55 \%$ & Very high \\
\hline P-Bray II & $9,15 \mathrm{mg} \mathrm{kg}^{-1}$ & $5,50 \mathrm{mS} \mathrm{cm}^{-1}$ \\
\hline Electrical Conductivity & & \\
\hline
\end{tabular}

Source : Agriculture's laboratory of syiahkuala university

The results showed that varieties had a very significant effect on the growth of chili plants. The best varieties of the best generative phase are found in PM 999 varieties which can be seen in the variable number of fruits, weight of fruit, weight of wet berasan, wet weight of roots and length of roots. The best growth of chili plants found in the Lado variety Assessment of the effect of salinity on growth and biochemical attributes in testing five Chilean chili cultivars which leads us to conclude that all parameters considered are significantly affected by salt stress especially at the highest salt levels (Kaouther et al., 2013)

High salinity can inhibit roots and elongate because it slows the water uptake by plants. shows that salinity can quickly inhibit root growth and its capacity to absorb water and essential mineral nutrients from the soil. Reduction of shoot dry weight can also be associated with reduced leaf production levels, so a low number of leaves causes reduced photosynthesis and dry matter accumulation (Neumann, 1997)

Perintis varieties are hybrid varieties that have superior characteristics but in saline land this variety will not good in the growth and yield phases, the fact in the field shows that pioneer variety are not as good as other varieties, Soegito and Adi (1993) state that hybrid varieties have many advantages. Wichis not owned by local varieties, therefore the use of superior hybrid varieties can increase the production of both quantity and quality as well as the level of resistance there are attacks of plant pest organisms and response to fertilization. ) This is in line with Simatupang (1997) which states the production of a variety is due to being able to adapt a variety to its environment, although genotypically other varieties have good potential. According to Adisarwanto (2000), varieties resistance to pest attacks, temperature, soil $\mathrm{pH}$ and others. Varieties that are able to survive with environmental conditions and can grow well and superior properties possessed by varieties if planted in optimal conditions will reach the potential results and that is so the apposite.

The difference in the response of each variable in each variety to salinity stress can be caused by differences in the tolerance mechanisms of each variable and the genetic factor of the variety (Kusuma, 2017). Botia et al., (1998) state that differences in salt tolerance levels are not only between different species, but also in the same species. Effect of mycorrhiza species on yield of chili plants on saline land

The results of the research showed that the type of mycorrhiza had a significant effect on the number of fruits, but it had no significant effect on other parameters. The growth and yield of chilli plants were best found in the type of mycorrhizal Glomus moseae $10 \mathrm{~g} /$ plant. In this case there is a clear difference in plant growth in saline soil conditions between plants with the application of mycorrhizae with plants without the application of mycorrhiza. This research also supports Chandrasekaran (2014) in his research stating that mycorrhiza plants have extensive root properties and morphological properties of mycorrhiza that help absorb more $\mathrm{P}$ and $\mathrm{K}$, together with increased production of antioxidant enzymes which result in reduced salt stress and increased biomass of plant. 
According to Evelin et al., (2012) Under the pressure of salt, mycorrhiza plants showed better growth, lower leaf aging, and decreased lipid peroxidation compared to plants without mycorrhiza. Stress salts affect root nodulation and NPK uptake. This effect is attenuated in mycorrhiza plants. The presence of AM fungus prevents excessive absorption of $\mathrm{Na}+$ by increasing $\mathrm{NaCl}$ in the soil. It also has a regulatory effect on the translocation of $\mathrm{Na}+$ ions into buds, thus maintaining lower $\mathrm{Na}+$ shoots: root ratio compared to plants without mycorrhiza. According to Porass et al.,(2009) Osmotic pressure caused by $\mathrm{NaCl}$ supply reduces stem diameter, but AMF colonization reduces all of these negative effects on growth. G. mosseae is the most efficient fungus in reducing the detrimental effects of salinity; increase shoot growth by $163 \%$ and root growth by $295 \%$ in non-saline medium, and $239 \%$ (shoot) and $468 \%$ (root) under saline conditions.

The mutualistic symbiotic relationship makes them both benefit for their lives. There are five benefits of mycorrhiza for the development of host plants, which increase nutrient absorption from the soil, as a biological barrier to root pathogen infections, increase host resistance to drought, increase growth booster hormones, and ensure the implementation of biochemical activities (Madjid, 2009). Mycorrhiza fungus can help encourage soil aggregation so that it can increase aeration, water absorption and soil stability. In addition, mycorrhiza fungi also play a role in controlling plant diseases. This is because this fungus uses more carbohydrates than roots, before being released in the form of root exudates, which can produce antibiotics, and spur the development of saprophytic microbes around the root area, so that pathogens are not able to develop (Talanca and Adnan, 2005).

This is in line with Ronco et al., (2018) which states that Horticulture is the best field for the use of AMF for nurseries. There are two main benefits of introducing mycorrhiza fungi to horticulture plants, which are stronger growth in nurseries and improved performance after planting in the field. Chili (Capsicum annuum L.) is one of the most common plants produced in nurseries, and one of the most important in Argentina's horticultural region.

\section{Conclusion:-}

Varieties significantly influencing the wet stover weight of 110 DAP, the number of fruit per plant 110 DAP, dry weight of plant fruit 110 DAP, significantly affected the fruit weight of per 110 DAP. The best chilli yield is found in PM 999 variety.

The type of mycorrhiza has a very significant effect on the number of fruit crops. The best chilli plants were found in the type of mycorrhiza Glomus Moseae. There is no real interaction between chili varieties with mycorrhiza types on the yield of chilli plants on saline land.

\section{References:-}

1. Adisarwanto. 2000. Increasing Peanut Production in Paddy Fields and Dry Land. PenebarSwadaya. Jakarta.

2. Bacerra, A., N. Bartoloni, N. Cofre, F. Soteras, and M. Cabello(2014). Arbuscular mycorrhizal fungi in saline soils: Vertical distribution at different soil depth. Brazilian Journal of Microbiology. 45(2): 585-594

3. Botia,P., M.Carvajal.,A. Cerda and V. Martine (1998). Response of eightCucumismeloCultivars to Salinity during Germination and Early Vegetative Growth. Ageonomie.18(8-9): 503-513

4. Chandrasekaran. M., S. Boughattas., SJ. Hu., SH .Oh., TM. Sa (2014). A meta-analysis of arbuscular mycorrhizal effects on plants grown under salt stress. Mycorrhiza 24: 611-625.

5. Evelin h., b .giri., r. Kapoor (2012). Contribution of glomusintraradices inoculation to nutrient acquisition and mitigation of ionic imbalance in nacl-stressed trigonellafoenum-graecum.mycorrhiza.22: 203-217.

6. Kaouther.Z., N. Hermans., R. Ahmad., and C. Hannachi.(2013).Evaluation of Salt Tolerance (NaCl) in Tunisian Chili Pepper (Capsicum frutescensL.) on Growth, Mineral Analysis and Solutes Synthesis. Journal of Stress Physiology \& Biochemistry, 9(1) : 209-228.

7. Kartasapoetra. A. G and M. M Sutedjo (1988). Rice Plant Cultivation in Tidal Swamp Land . PT Bina Angkasa, Jakarta.

8. Kusuma. M. D., I. Yulianah and S.L. Purnamaningsih (2017). Salinity tolerance test in various capsicum annuum varieties. Journal of Plant Production.5 (6): 911-916.

9. Lopez. M.A.H, A.L. Ulery, Z. Samani, G. Picchioni and R.P Flynn (2011). Response of Chile Pepper (Capsicum annuumL.) to Salt Stress and Organic and Inorganic Nitrogen Sources Growth and Yield. Tropical and Subtropical Agroecosystems, $14: 137-147$. 
10. Madjid, A. 2009.Basics of Soil Science.Online Teaching Materials.Faculty of Agriculture Unsri\& Plant Sciences Study Program, Sriwijaya University. Palembang. South Sumatra Province. Indonesia. 30 p. Meyr (2005).

11. Neumann P (1997). Salinity resistance and plant growth revisited. Plant, Cell \& Environment; 20(9):1193-8.

12. Porras S.A., ML. Soriano., P.A. Porras., R. Azcon (2009). Arbuscular mycorrhizal fungi increased growth, nutrient uptake and tolerance to salinity in olive trees under nursery conditions. J Plant Physiol 166: 1350-1359

13. Ronco, M., M. Ruscitti,, M. Arango., J. Beltrano (2008). Glyphosate and micorrización induce changes in plant growth and in root morphology and architecture in pepper plants (Capsicum annum L.). J. Horticult. Sci. Biotechnol. 83, 497-505

14. Simatupang, S. 1997. Nature and Characteristics of Soil.Bogor Agricultural Institute. Bogor.

15. Sipayung, R., 2003. Salt Stress and Plant Tolerance Mechanism.Faculty.Agriculture Department of Agriculture, University of North Sumatra, Medan.

16. Suhartina (2005).Description of Superior Beans and Bean Bulbs.Research Institute for Peanut and Tuber Crops. Malang. Indonesia.

17. Talanca A. H and A. M. Adnan. 2005. Mycorrhizae and their Benefits in Plants. Cereal Crop Research Institute. Maros.South Sulawesi. 